\title{
Diversity of Hoverfly (Diptera: Syrphidae) Communities in Different Habitat Types in Zanjan Province, Iran
}

\author{
Masumeh Naderloo and Shahrokh Pashaei Rad \\ Department of Zoology, Faculty of Biological Science, Shahid Beheshti University, G.C., Tehran, Iran \\ Correspondence should be addressed to Masumeh Naderloo; ma.naderlu@gmail.com
}

Received 26 November 2013; Accepted 16 December 2013; Published 22 January 2014

Academic Editors: A. Ramirez-Bautista and C. P. Wheater

Copyright (C) 2014 M. Naderloo and S. Pashaei Rad. This is an open access article distributed under the Creative Commons Attribution License, which permits unrestricted use, distribution, and reproduction in any medium, provided the original work is properly cited.

\begin{abstract}
The diversity of hoverfly communities was studied in four different habitat types (river side, woodland, fruit garden, and rice field) in the years of 2008 and 2009. Adult hoverflies were collected from different habitants in Zanjan province. A total of 31 species with 750 individuals of hoverflies were collected, among which Sphaerophoria scripta (Linnaeus), Eristalis arbustorum (Linnaeus) and Eristalis tenax (Linnaeus) were found to be the most abundant. Records from these four sites were used in the diversity analysis. The results indicated that river side and rice field showed the highest and lowest degree of species richness and species diversity. Also, river side and rice field showed the highest and lowest species evenness, respectively.
\end{abstract}

\section{Introduction}

The Syrphidae family, commonly named hoverflies or flower flies, comprises almost 6000 species worldwide and is one of the largest families of Diptera [1]. The adults feed on nectar and pollen of flowering plants. They are considered an important group of insects in agriculture and play a major role as pollinators [2].

While almost all the adult hoverflies feed on pollen or nectar, Syrphid larvae show heterogeneous alimentary habits. Larval feeding modes of Syrphidae include phytophagous (Eumerus Meigen and Merodon Meigen), mycetophagous (Celosia Meigen), saprophagous (most Milesiinae), and zoophagous (Syrphinae and Pipizini). Aphidophagous hoverflies are important as biological control agents of various aphids [2].

Hoverflies can be found everywhere except in dry area. Each species tends to prefer a certain type of habitat and is limited to a distinct range within the country. So adult hoverflies can be collected where they feed on flowers, some in places where they oviposit and where they hover in sunlight or rest on foliage [3].
Because the Syrphidae larvae can be found in a broad range of land cover types, and the adults are mostly found in areas with flowers, a very heterogeneous land cover type will contain most of the (a) biotic factors needed by the majority of the hoverflies. This will implicate that, when the heterogeneity of the land cover type will increase, this will have a positive effect on the biodiversity of the hoverflies. Due to dependence on flowers in their adult stage areas with a large amount of different flowers (mostly of the Umbelliferae family) will increase locally the hover flies species diversity. The majority of the hoverflies can be found within diverse habitats like forests, woodlands, marches, bogs, gardens peat land and residential areas [4]. Due to highly diversified habitat requirements of their larvae hoverflies are particularly negatively affected by reduction in landscape diversity. They can function as good biological indicators of environmental stress and of loss of landscape diversity. Heterogeneous land cover types will increase hoverflies species [5]. In general, insect diversity is highest in habitats with the most plant diversity and is lowest in shrub, grass, and open areas [6].

Because hover flies provide important ecological services for crops and native wild plant species in many ecosystems of 
the world and as biological control agents against pests, their conservation is essential to sustain the productivity of natural and agricultural landscapes [7].

The aim of this study was to collect information on the current status of hover flies in four different habitat types (River side, Woodland, Fruit garden, and Rice field). The specific objectives were to characterize hover fly assemblages (abundance, species richness and diversity) in four different habitat types that had small-scale vegetation type patterns.

\section{Materials and Methods}

2.1. Study area. Zanjan province, in northwest of Iran, is located in $35^{\circ} 35^{\prime}$ to $37^{\circ} 15^{\prime} \mathrm{N}, 47^{\circ} 15^{\prime}$ to $49^{\circ} 25^{\prime} \mathrm{E}$ with varying altitude from $270 \mathrm{~m}$ to $3400 \mathrm{~m}$. This region has a highland climate characterized by cold snowy weather in the mountains and moderate climate in the plains in winter time. In the summers, the weather is warm. The average maximum temperature of Zanjan is around $27^{\circ} \mathrm{C}$, whereas the average minimum temperature stands at $-19^{\circ} \mathrm{C}$. Meanwhile, the temperature rises to $32^{\circ} \mathrm{C}$ on hot days, whereas it drops to $-27^{\circ} \mathrm{C}$ below zero on icy days. The average annual rainfall in the first month of spring stands at 72 millimeters, while in the second month of summer, it slips to a meager $3.6 \mathrm{~mm}$. The rate of humidity in the morning stands by average at $74 \%$ and at noon at $43 \%$.

2.2. Sampling Method. In order to study diversity of hoverflies in four different habitat types (river side, woodland, fruit garden, and rice field), adult specimens were collected with sweep net in different periods between May and September 2008-2009. Sampling was carried out at the same time of the day throughout the survey, 8-12 a.m. in spring and summer. The collected materials were determined by different keys especially Stubbs and Falk [3] and Bei-Bienko [8]. The identified samples were sent to Dr. Barkalov (Siberian Zoological Museum) and were confirmed. Geographical characteristics of sampling stations were determined by GPS (Table 1).

2.3. Data Analysis. For data analysis, indices of diversity, evenness, and species richness of hoverflies were assessed for each habitat type, and calculated using Ecological Methodology software [9]. If the number of individuals in different habitats was the same, we were able to calculate species richness by direct counting. But since the number of individuals was not the same in different habitats, therefore we generated an average species accumulation curve, based on 160 randomizations, and calculated rarefied species richness at equal sampling effort (number of samples) among sites ("rarefied richness" [10]). Rarefaction is a statistical method for estimating the number of species expected in a random sample of individuals taken from a collection. So we used the same curves to estimate the extrapolated total species richness, using a Michaelis-Menten equation ("extrapolated richness" [11]). The similarity of species composition between habitat types (Bray-Curtis similarity with square root transformation) was analyzed with Cluster analysis using Past 1.88 software [12].
TABLE 1: Geographical and Vegetation characteristics of sampling stations.

\begin{tabular}{|c|c|c|c|c|}
\hline Locality & Vegetation & Latitude & Longitude & Altitude \\
\hline River side & $\begin{array}{l}\text { Shrub and grass } \\
\text { habitats around } \\
\text { Zanjanrood River }\end{array}$ & $36^{\circ} 38^{\prime} \mathrm{N}$ & $48^{\circ} 32^{\prime} \mathrm{E}$ & $1637 \mathrm{~m}$ \\
\hline Woodland & $\begin{array}{c}\text { Almost Salix trees near } \\
\text { Taham dam }\end{array}$ & $36^{\circ} 47^{\prime} \mathrm{N}$ & $48^{\circ} 33^{\prime} \mathrm{E}$ & $1875 \mathrm{~m}$ \\
\hline Rice field & $\begin{array}{l}\text { Rice field and around } \\
\text { grassland }\end{array}$ & $36^{\circ} 49^{\prime} \mathrm{N}$ & $49^{\circ} 05^{\prime} \mathrm{E}$ & $350 \mathrm{~m}$ \\
\hline Fruit garden & $\begin{array}{l}\text { Apricot and apple } \\
\text { trees }\end{array}$ & $36^{\circ} 16^{\prime} \mathrm{N}$ & $48^{\circ} 42^{\prime} \mathrm{E}$ & $2015 \mathrm{~m}$ \\
\hline
\end{tabular}

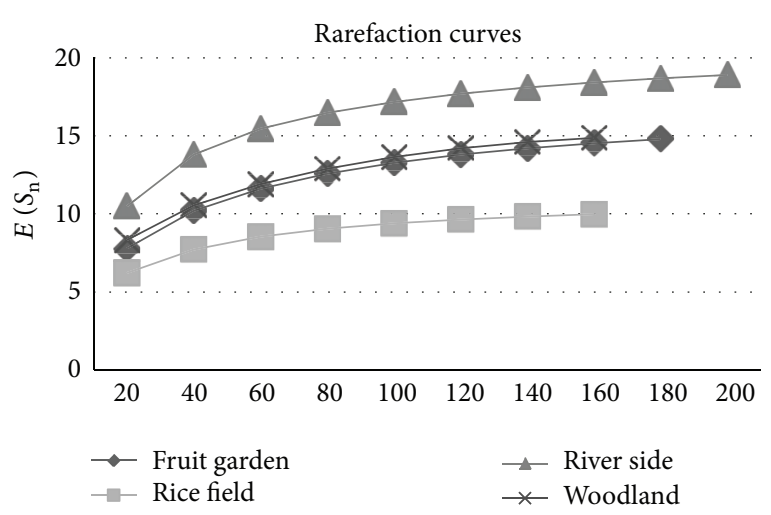

FIGURE 1: Species richness curves of hoverfly communities in four different habitat types.

\section{Results}

In total, 750 individuals of 31 species belonging to 16 genera from eight tribes and two subfamilies of hoverflies were recorded in four different habitat types in the studied period in 2008-2009. The hoverflies list and their abundance are presented in Table 2. The members of the subfamily Syrphinae were in greater abundance (459 individuals) than members of Milesiinae (291 individuals) in the overall study period.

The three most abundant species are Sphaerophoria script (27.2\%), Eristalis arbustorum (12.5\%), and Eristalis tenax (11\%). The greatest number of individuals of Sphaerophoria script occurred in rice flied with 71 individuals, while most of Eristalis arbustorum were found in the fruit garden and woodland with 38 and 31 individuals, respectively.

The diversity of hoverfly communities in four different habitat types in Zanjan province is presented in Table 3. The river side has the greatest species number (19 species) and the rice field has the least (10 species). The river side has the greatest individual number (210 individuals); the rice field has the least individual number (164 individuals). Rarefaction method was used for comparison of species richness, as Figure 1 showed in spatial scale; based on 160 randomizations, river side and rice field showed the highest and lowest species richness, respectively. The Shannon-Wiener diversity index was calculated for different habitats. As Figure 2 showed the river side has the highest diversity index. Finally Simpson evenness index calculated. The evenness index is very high in 
TABLE 2: List of Syrphidae species in different habitat types in Zanjan province with general trophic level of larvae.

\begin{tabular}{|c|c|c|c|c|c|}
\hline \multirow{2}{*}{ Species } & \multicolumn{5}{|c|}{ Habitats } \\
\hline & River side & Woodland & Fruit garden & Rice field & Larval trophic category \\
\hline \multicolumn{6}{|l|}{ Subfamily Milesiinae } \\
\hline Eristalis arbustorum (Linnaeus) & 25 & 31 & 38 & 0 & Aquatic saprophgous \\
\hline Eristalis tenax (Linnaeus) & 28 & 21 & 34 & 0 & Aquatic saprophgous \\
\hline Eristalis similis Fallen & 2 & 0 & 0 & 0 & Aquatic saprophgous \\
\hline Eristalinus megacephalus (Rossi) & 1 & 0 & 0 & 0 & Aquatic saprophgous \\
\hline Eristalinus sepulchralis (Linnaeus) & 15 & 0 & 0 & 0 & Aquatic saprophgous \\
\hline Eristalinua aeneus (Scopoli) & 9 & 0 & 4 & 0 & Aquatic saprophgous \\
\hline Eristalinus taneniops (Wiedemann) & 2 & 2 & 0 & 0 & Aquatic saprophgous \\
\hline Helophilus continuus Loew & 1 & 0 & 0 & 0 & Aquatic saprophgous \\
\hline Eumerus strigatus (Fallen) & 4 & 2 & 0 & 0 & Phytophagous \\
\hline Eumerus sogdianus Stackelberg & 5 & 3 & 0 & 0 & Phytophagous \\
\hline Syritta pipiens (Linnaeus) & 15 & 12 & 17 & 0 & Terrestrial saprophagous \\
\hline Pipizella divicoi (Goeldlin) & 12 & 0 & 2 & 0 & Predator \\
\hline \multicolumn{6}{|l|}{ Subfamily Syrphinae } \\
\hline Neoascia podagrica (Fabricius) & 6 & 0 & 0 & 0 & Semi-aquatic \\
\hline Paragus quadrifasciatus Meigen & 0 & 0 & 3 & 2 & predator \\
\hline Paragus compeditus (Wiedemann) & 0 & 0 & 0 & 7 & Predator \\
\hline Paragus abrogans (Goeldlin) & 0 & 0 & 0 & 3 & Predator \\
\hline Paragus bicolor (Fabricius) & 6 & 3 & 5 & 0 & Predator \\
\hline Paragus albifrons (Fallen) & 0 & 0 & 0 & 1 & Predator \\
\hline Ischiodon scutellaris (Fabricius) & 0 & 0 & 0 & 7 & Predator \\
\hline Scaeva pyrastri (Linnaeus) & 0 & 0 & 1 & 0 & Predator \\
\hline Scaeva albamaculata (Macquart) & 0 & 2 & 0 & 0 & Predator \\
\hline Sphaerophoria scripta (Linnaeus) & 31 & 44 & 58 & 69 & Predator \\
\hline Sphaerophoria turkmenica Bankowska & 0 & 5 & 12 & 0 & Predator \\
\hline Sphaerophoria ruppelli (Wiedemann) & 4 & 0 & 2 & 29 & Predator \\
\hline Eupeodes corolla (Fabricius) & 21 & 14 & 8 & 20 & Predator \\
\hline Eupeodes nuba (Wiedemann) & 0 & 17 & 0 & 0 & Predator \\
\hline Meliscaeva auricollis (Meigen) & 0 & 1 & 0 & 0 & Predator \\
\hline Spazigaster ambulans (Fabricius) & 0 & 2 & 0 & 0 & Predator \\
\hline Melanostoma mellinum (Linnaeus) & 8 & 0 & 5 & 19 & Predator \\
\hline Episyrphus balteatus (De Geer) & 18 & 18 & 9 & 15 & Predator \\
\hline Platycheirus sp (Lepeletier and Serville) & 0 & 0 & 1 & 0 & Predator \\
\hline
\end{tabular}

TABLE 3: Diversity of hoverfly communities in four different habitat types in Zanjan province.

\begin{tabular}{lccccc}
\hline Habitat types & Species number $(S)$ & Individual number $(N)$ & Species richness index $E(S n)$ & Evenness index $E(1 / D)$ & Diversity index $\left(H^{\prime}\right)$ \\
\hline River side & 19 & 210 & 18.4 & 0.593 & 3.695 \\
Woodland & 15 & 177 & 14.86 & 0.48 & 3.13 \\
Fruit garden & 15 & 199 & 14.4 & 0.398 & 2.948 \\
Rice field & 10 & 164 & 9.97 & 0.397 & 2.4 \\
\hline
\end{tabular}

river side (Figure 3). The high evenness index of the river side leads to the high diversity index. The similarity of hoverflies communities between habitats is displayed in Figure 4. BrayCurtis analysis established that the similarity of hoverflies among habitats was rather different (67\%). Figure 4 shows that the similarity of species composition was highest among woodland and fruit garden (84\%), and also high between fruit garden and river side (82\%). High differences were found between rice field and other habitats, especially with river side (67\%).

\section{Discussion}

Species belonging to the subfamily Syrphinae are abundant species in four different habitat types in the studied area, and with 19 species have the most diversity. The larvae of all the 


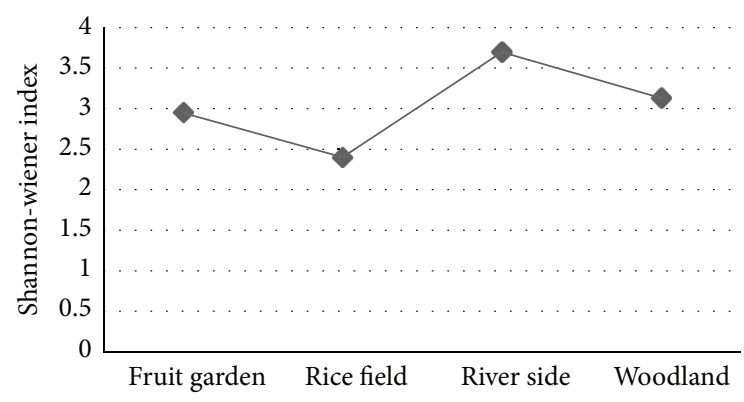

FIGURE 2: Shannon-Wiener diversity index of hoverfly communities in four different habitat types.

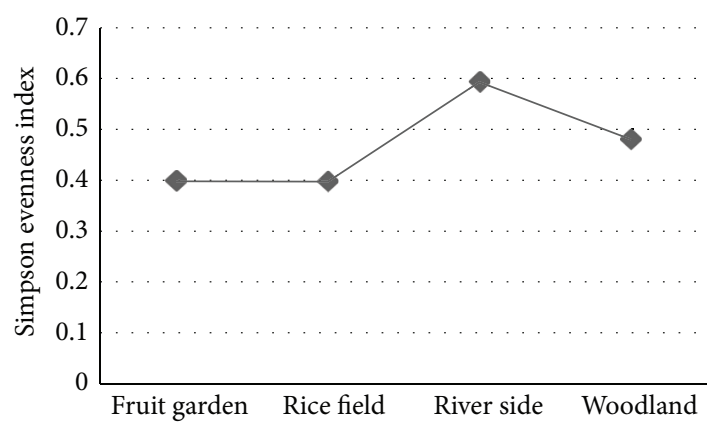

FIGURE 3: Simpson evenness index of hoverfly communities in four different habitat types.

species collected from the subfamily Syrphinae were aphidophagous whereas all those from the subfamily Milesiinae except Pipizella divicoi were saprophagous. The abundance of aphidophagous species was greater than that of saprophagous species in this study. It was expected because some parts of the studying habitats were agriculture ecosystem and garden. The abundance of any species in a specific habitat and specific interval of time is related to availability of breeding places and hosts. Most of members of Milesiinae breed in marshes, wettish places, and rotting materials [7]. Since the Syrphinae are entirely aphidophagous, they lay eggs near or in the aphid colonies on the plants. Most of aphid species in the study habitats of Zanjan province appeared in May and June, suggesting that larval diet is also very important in determining population dynamics of aphidophagous species. The result indicated that in the study areas the more abundant species are Sphaerophoria script, Eristalis arbustorum, and Eristalis tenax. They are widely distributed and active in most seasons, and have long-flight period. These species have adapted to a wide range of geographic patterns, therefore they could be considered as the most successful hoverflies species [2]. Sphaerophoria script is more abundant in rice field because this species has aphidophagous larvae. Predatory taxa were much more in corps and can be related to the occurrence of high densities of aphids population in fields [13]. The rice field consists of very simple vegetations, mostly rice bunches. The less diversity of vegetation results in less diversity of hoverflies. Studies show that the more diverse plants are the more diverse pollinator species and insects are

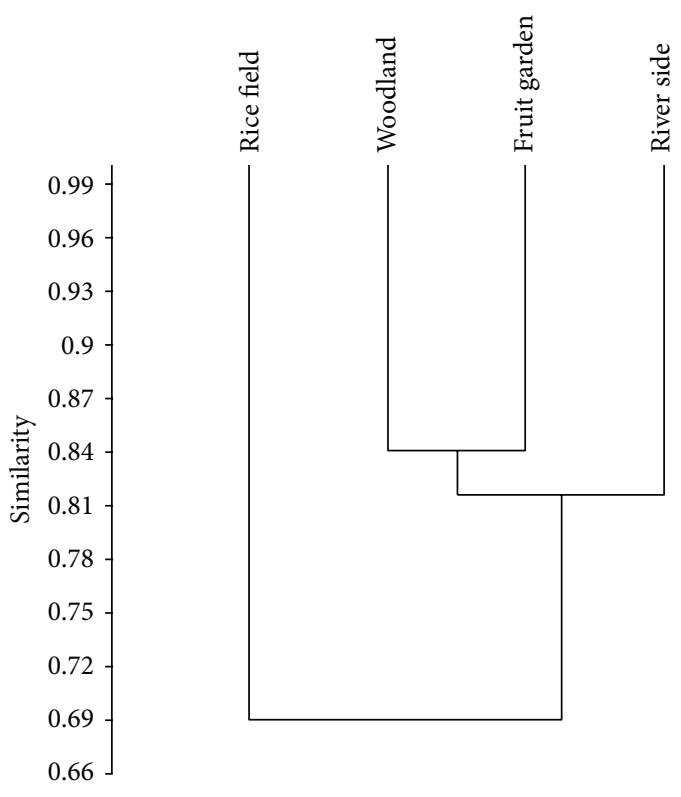

FIgURE 4: Cluster of similarity between habitats based on the hoverflies species.

[8]. The fruit garden has fewer hoverfly species than the river side. River side has more species than the woodland. Rice field has the least species number. Living environment of river side is no homogeneous with a variety of land cover types in the intermediate procession. The river side has the greatest abundance of hoverflies and species. The living environment of the river side is diversified with vegetation, shrub, grass, mud and water that attract more hoverflies as they land taking water and feed on flowers. Also, river side is a suitable place for their larvae because 9 species of 19 species which were collected in this area have aquatic and semiaquatic larvae. Large saprophages larvae are mostly restricted to water during their development. Large relative surfaces of water may support larger populations which are less prone to extinction. This may subsequently cause higher species richness in areas with more wetlands [14]. So there is greater insect diversity in the wet sites than in the dry sites. Along the river, shrub and grass with flowering plants also support more hoverflies. The hoverflies usually inhabit in humid areas in forests in high mountains as well as habitats on river banks in forests where flowering plants grow [15]. Also, woodland and fruit garden have high species diversity after river side respectively. The majority of the hoverflies fauna in Atlantic Europe use woodlands as shelter. With an increase in land cover types woody plants and trees will be included, which presumably will lead to an increase in hoverflies species.

A study carried out by Humphrey et al. [16] showed that hoverflies diversity, within pine and spruce diversity forests in the UK, showed a high correlation with landscape complexity. Due to a need for different habitats during their life and the diversity of different larvae situations the diversity of land cover could play a more important role in diversity of hoverflies, so the rice filed is monoculture place and the lack of habitat diversity will lead to a decrease in hoverflies species. 
Jeanneret et al. [17] found a similar positive relation between butterflies assemblages and plant species richness.

In addition, the diverse variety of larval development habitats allows occupation of a wide spectrum of forest habitats [18].

This is reflected in the differences in hoverflies fauna composition at the four different habitats.

Romero-Alcaraz and Ávila [19] concluded that habitat heterogeneity at a landscape scale explains the diversity of epigaeic beetles of a Mediterranean ecosystem.

Finally, the research carried out by Magagula and Samways [20] pointed out the positive influence landscape heterogeneity (variety of habitats) has on plant diversity and by this on the coccinellid diversity. The more heterogeneous the landscape is, the higher habitat heterogeneity will be and this could lead to more species diversity [21].

Species composition was dissimilar among habitats, but rather similar between the fruit garden and woodland habitats, and between fruit garden and river side. The hoverfly species compositions between the rice field and other habitats were rather dissimilar. The most aphidophagous hoverflies (164 individuals) were abundant in rice field, so we collected more of them in this place. Aphidophagous species were much in corps and can be related to density of aphid's population in fields [13]. But the most number of aquatic saprophagous species was found in river side, so there were no aquatic saprophagous species in rice field. Therefore we observed less similarity between river side and rice field. River side was a suitable place for aquatic and semiaquatic hoverflies. High similarity was found between fruit garden and woodland, because the most part of these habitats were woody plants and trees, so the majority of hoverflies uses woodlands as shelter. The increased number of woody plants and trees occurs to increased population of hoverflies, too [16].

\section{Conflict of Interests}

The authors declare that there is no conflict of interests regarding the publication of this paper.

\section{Acknowledgment}

Authors are very grateful to Dr. Anatoli Barkalov from Siberian Zoological Museum, Russia, for his help in species confirmation.

\section{References}

[1] S. Y. Kuzentsov, "The phylogeny of the family syrphidae (Diptera)," in Proceedings of the 12th Congress of Russian Entomological Society, p. 189, 2002.

[2] M. C. D. Speight, "Database of Irish Syrphidae (Diptera)," Irish Wildlife Manuals, vol. 36, p. 344, 2008.

[3] A. Stubbs and S. Falk, British Hoverflies. An Illustrated Identification Guide, British Entomological \& Natural History Society, Reading, UK, 1996.

[4] M. van Veen, Hoverflies of Northwest Europe, Identification Keys to the Syrphidae, KNNV Publishing, Utrecht, The Netherlands, 2004.
[5] W. Büchs, "Biodiversity and agri-environmental indicatorsgeneral scopes and skills with special reference to the habitat level," Agriculture, Ecosystems and Environment, vol. 98, no. 1-3, pp. 35-78, 2003.

[6] R. G. de Vries, Outlines of Entomology,, Chapman \& Hall/CRC, Boca Raton, Fla, USA, 7th edition, 1992.

[7] D. Sommaggio, "Syrphidae: can they be used as environmental bioindicators?" Agriculture, Ecosystems and Environment, vol. 74, no. 1-3, pp. 343-356, 1999.

[8] G. Y. Bei-Bienko, "Keys to the Insects of the European part of USSR," Diptera and Siphonoptera, vol. 5, no. 46, pp. 10-148, 1988.

[9] C. J. Krebs, Ecological Methodology, Harper Collins, New York, NY, USA, 1989.

[10] N. J. Gotelli and G. R. Graves, Null Models in Ecology, Smithsonian Institution Press, Washington, DC, USA, 1996.

[11] R. K. Colwell and J. A. Coddington, "Estimating terrestrial biodiversity through extrapolation," Philosophical Transactions of the Royal Society of London B, vol. 345, no. 1311, pp. 101-118, 1994.

[12] Ø. Hammer, D. A. T. Harper, and P. D. Ryan, "Past: paleontological statistics software package for education and data analysis," Palaeontologia Electronica, vol. 4, no. 1, pp. 19-20, 2001.

[13] F. Francis, E. Haubruge, P. Colignon, P. Hastir, and Ch. Gaspar, "Entomological diversity in agro-ecosystems: not necessarily an ecological desert," Biologie, vol. 72, pp. 153-154, 2002.

[14] P. Keil, F. Dziock, and D. Storch, "Geographical patterns of hoverfly (Diptera, Syrphidae) functional groups in Europe: inconsistency in environmental correlates and latitudinal trends," Ecological Entomology, vol. 33, pp. 748-757, 2008.

[15] S. Saribiyik, "Contributions to the syrphidae fauna of Turkey (Diptera: Syrphidae)," Entomological News, vol. 119, no. 5, pp. 501-508, 2008.

[16] J. W. Humphrey, C. Hawes, A. J. Peace, R. Ferris-Kaan, and M. R. Jukes, "Relationships between insect diversity and habitat characteristics in plantation forests," Forest Ecology and Management, vol. 113, no. 1, pp. 11-21, 1999.

[17] P. Jeanneret, B. Schüpbach, and H. Luka, "Quantifying the impact of landscape and habitat features on biodiversity in cultivated landscapes," Agriculture, Ecosystems and Environment, vol. 98, no. 1-3, pp. 311-320, 2003.

[18] M. De Meyer, "Biogeography, diversity and seasonality of Syrphidae (Diptera) in a Guineo-Congolian rain forest in Kenia," Journal of East African Natural History, vol. 90, pp. 87-101, 2001.

[19] E. Romero-Alcaraz and J. M. Ávila, "Landscape heterogeneity in relation to variations in epigaeic beetle diversity of a Mediterranean ecosystem. Implications for conservation," Biodiversity and Conservation, vol. 9, no. 7, pp. 985-1005, 2000.

[20] C. N. Magagula and M. J. Samways, "Maintenance of ladybeetle diversity across a heterogeneous African agricultural/savanna land mosaic," Biodiversity and Conservation, vol. 10, no. 2, pp. 209-222, 2001.

[21] J. T. Rottenberry and J. A. Wiens, "Habitat structure, patchiness, and avian communities in North American steppe vegetation: a multivariate analysis," Ecology, vol. 6, pp. 1228-1250, 1980. 

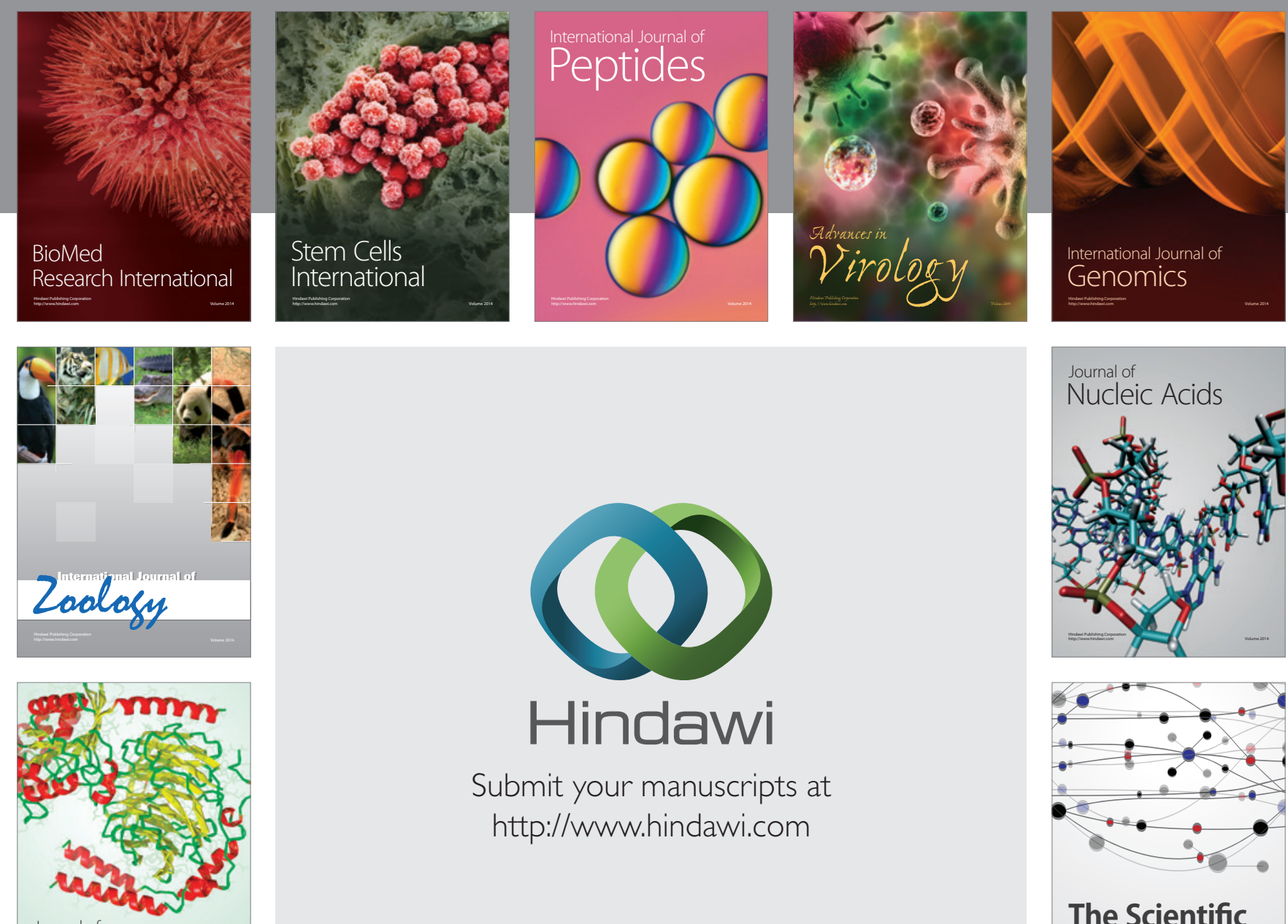

Submit your manuscripts at

http://www.hindawi.com

Journal of
Signal Transduction
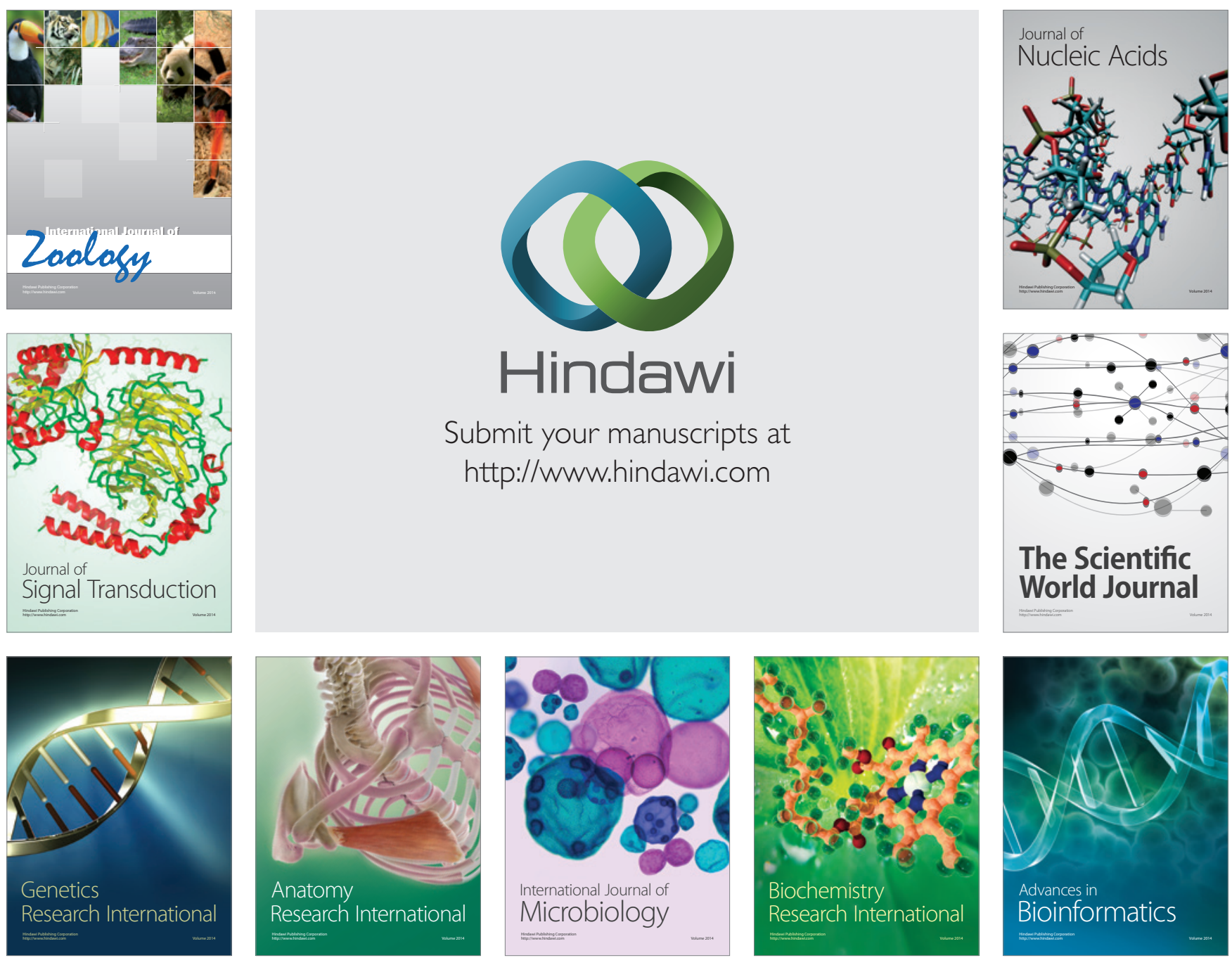

The Scientific World Journal
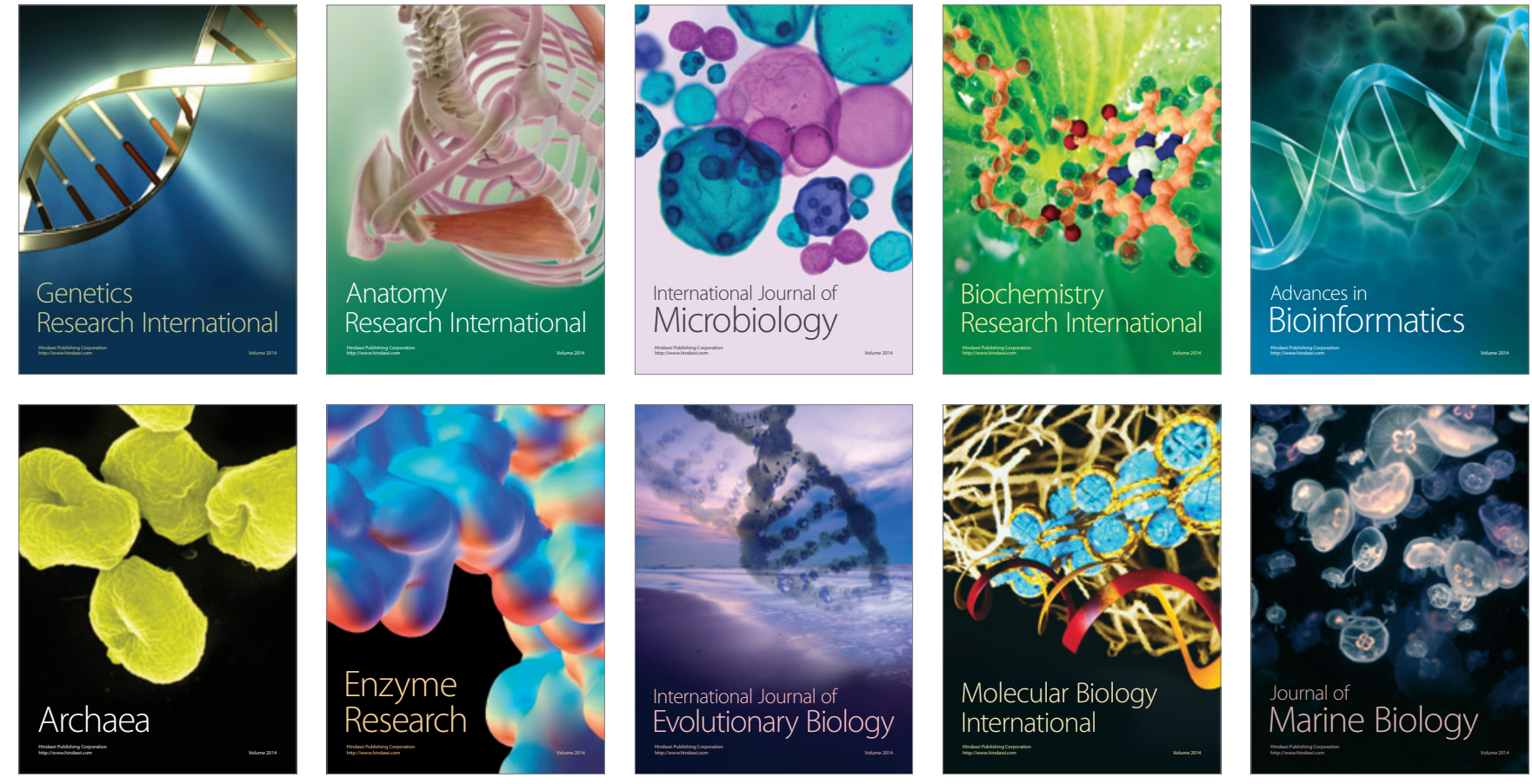